\title{
The Use Mobile Learning in Higher Education: What Were the Cause of Student's Satisfaction on Civic Education Learning Use
}

\author{
Restu Adi Nugraha ${ }^{1, *}$, Dasim Budimansyah ${ }^{2}$ \\ ${ }^{1,2}$ Universitas Pendidikan Indonesia, Bandung, Indonesia \\ *Corresponding author. Email: restuadinugraha@upi.edu
}

\begin{abstract}
In the 21st-century competency framework, one of the indicators that can support competence is media information and technology. Higher education in Indonesia has been able to provide E-Learning (EL) experiences to their students, but not many use platform mobile tools. The use of digital media in the learning process is not fully effective, several problems that hinder the success of digital learning, one of which is limited tools, internet quotas, and learning content that is not by student needs, some untapped potential in digital learning systems also affect sustainability, EL one of which is learning innovations such as Mobile Learning (ML). This study aims to identify student satisfaction using ML which is measured as a direct measure of the results and predictors that have an impact on it. This survey collected data from 384 students using ML who were randomly selected because they were enrolled in eight faculties at Universitas Pendidikan Indonesia. They used ML applications in the Pancasila Education \& Civic Education course on the Blended Learning (BL) system in 2021. This study uses a survey method with univariate and bivariate analyst techniques. The results show that students are satisfied with varied and innovative learning content, students as digital citizens need to be skilled in the use of digital media, after students are skilled, students will easily use and access applications of ML. Through varied, innovative learning content, speed of information, ease of access for any literature can motivate students to learn independently by using ML.
\end{abstract}

Keywords: Blended Learning, Civic Education, General Education, Mobile Learning, Student Satisfaction

\section{INTRODUCTION}

Technological developments in Indonesia have undergone quite dynamic changes that have an impact on various fields, including the field of education. Education in Indonesia has led to a 21 st-century pattern, this change occurs when there is a change in the curriculum from time to time that leads to alldigital learning. In this 21 st-century, the use of technology has become increasingly intensive at all ages, especially students. Indonesia, with a large population, should develop technology for survival, including in making 21st century learning effective. Data obtained from the Internet World Stats Top 20 Countries with Highest Number of Internet Users June 30, Indonesia ranks 4th in the world at $171,260,000$ internet users with an increase of $8,463 \%$ from 2000 to 2019 [1]. This shows that Indonesian society is a technology-consumptive society and requires digital devices to fulfill their lives.

The use of digital media in the learning process in the 21 st-century education era is likely to be developed especially for students, according to Butler's research that younger course participants are more likely to embrace ML technology than their older counterparts. They suggest that they use laptops, hybrids as well as smartphones and tablets to engage with m-learning applications at home and when they travel' [2].

The study stated that students could embrace digital media in the learning process, especially ML. Students can use smartphones and tablets to apply digital learning with student skills in using digital devices at home or even when they are traveling. The development of the use of digital devices must be maximized in 21 st-century education through the use of appropriate methods by educational goals. Sarker et. al in their research [3] revealed that technology must be integrated at all levels of the curriculum, in the input process, procedures, and learning methods to benefit from technological developments in the 21 st century. However, in reality in Indonesia the learning process that uses this technology there are several problems, the first problem concerns complaints of high internet quotas with a figure of $43 \%$ and then complaints of not having tools at $29 \%$ [4]. 
Digital technology has a major problem, namely limited access and internet quotas as well as tools that support the learning process, however, m-learning using smartphones includes the provision of podcasts (audio) or short videos that can be accessed via mobile phones, tablets, or mp3 players, which can improve learning at school class [5]. From this research, it can be understood that the ML system allows overcoming the problems of the Indonesian people, especially students who carry out online learning activities. Mobile learning overcomes this problem with minimalist learning media and content by using more sound learning content, graphic images, illustrations, and a few short videos or videos in online learning activities, with minimalist learning content allowing less use of internet quota in accessing learning that can overcome the main problems of digital learning.

M-learning counts mobile with E-Learning, it can be understood that ML is Self-Regulated Learning by learning anytime and anywhere (Distance Learning) [6]. However, there is another problem with digital media as a SLR Learning tool in the learning process, the research on Pereira et al., [7] stated that students as a digital society in the 21 st century still perceive digital media as entertainment media, and few of them utilizing digital media as learning media, students in need of digital media as learning media are used only when situations are important and urgently needed.

Talking about the use of digital media in supporting the learning process towards student learning independence, there are previous research results that need to be reviewed and underlie this research, according to the research results of Wang et al., [8] regarding Revisiting the Blended Learning Literature: Using a Complex Adaptive Systems Framework revealed that "The review identifies several gaps in current blended learning research and practice, and advances our understanding of some untapped potential of this new system of learning" according to the results of the study, identifies several gaps in mixed learning or digital-based learning, and shows some potential has not been used in the learning system in the network. This shows that there is potential that can be studied more deeply if it is integrated with more varied digital learning content or substances such as mobile learning in supporting digital learning, especially increasing student learning independence.

Thus, it can be understood that technology is the main tool that needs to be developed sustainably, especially in the field of education. Learning that runs optimally, especially in building student independence as digital citizenship who live in the digital era in the development of 21 st-century technology. Therefore, based on the description above, the researchers tried to examine the effect of using ML on online learning on SLR of students in the Compulsory Subjects of the Pancasila Education Curriculum \& Civic Education at the Universitas Pendidikan Indonesia.

\section{THEORETICAL REVIEW}

\section{1. $21^{\text {st }}$ Century Education}

21st-century education, UNESCO [9] has made 4 pillars of education, namely: 1) Learning to know, 2) Learning to do, 3) Learning to be, and 4) Learning to live together. Education that builds the competence of "Partnership 21st Century Learning" [10] is a 21stcentury learning framework that requires students to have skills, knowledge, and abilities in the fields of technology, media and information, learning skills, innovation, and life skills.

Learning to know, learning to know is an activity to acquire, deepen and utilize knowledge material. Mastery of the material is one of the important things for students in the 21 st century. Students must also have the will to learn for life. It can be understood that students must continuously assess their abilities about what they already know and continue to feel the need to strengthen their understanding for their future success. Students must be ready to always learn when facing new situations that require new skills.

Learning to do, To be able to adapt and adapt in a society that is developing very quickly, individuals need to learn to work. Students and adults alike need academic and applied knowledge, can connect knowledge and skills, be creative and adaptive, and be able to transform all these aspects into valuable skills. The US-based Partnership for 21st Century Skills (P21) [10] identified the competencies needed in the $21 \mathrm{st}$ century, namely "The 4Cs" - communication, collaboration, critical thinking, and creativity.

Thus it can be understood that the implementation of learning in the era of digital technology in the $21 \mathrm{st}$ century by utilizing digital-based media can be carried out both as a medium and as a source of learning in universities. Online digital-based media of information in the form of knowledge, besides being able to be used as a source of information and knowledge, can also act as a medium and source of learning. Through digital media, learning will attract the attention of students and will be able to generate learning motivation.

Ackoff and Dreenberg [11] that "education does not depend on teaching, but rather on the selfmotivated, curiosity and self-initiated actions of the learner". What can be understood is that education does not depend on the learning process, but on the motivation of students, curiosity, and student initiative actions, in the 21 st-century education pattern is not only skills that must be possessed and expertise in technology, but in supporting it in the learning process is how all aspects that support the course of effective learning can provide a stimulus for students to learn in the 21 st-century education pattern.

\subsection{Mobile Learning}

Mobile learning (ML) in Traxler's opinion defines as all educational provisions in which the dominant use of 
technology is handheld devices or platform devices [12]. ML can be defined as a digital device that is small enough that you can take it anywhere, this portable device can support learning in any situation flexibly, ML is a tool that accommodates and supports EL because ML itself is an integral part of EL in developing learning online on the pattern of $21 \mathrm{st}-$ century education.

Furthermore, Traxler defines in detail the characteristics of ML as follows, ML has core characteristics that define and can characterize ML itself, namely Spontaneous, Personal, Portable, Situation, Informal, Spending less Bandwidth, Lightweight, Context-aware, Connected, Personalized, and Interactive.

ML can be implemented by referring to Instructional design theory, according to Sadler-Smith, [13] revealed that instructional design can function as a balancing act by providing sufficient support and feedback from educators to students to excel in learning. Reinforcing this statement, according to Reigeluth [14] instructional design theory offers explicit guidance on how to help people learn and develop. Then, according to Arif S. Sadiman et al., [15] "The use of this smartphone was chosen to help to increase motivation and effectiveness of teaching and learning"

Thus it can be understood that ML is not a goal, but is a tool that facilitates EL that is more portable, flexible, lightweight, easy, and simple and supports online learning for students, and can overcome the problems of online learning that can consume a lot of bandwidth in the online learning process. Through supporting applications, ML needs to be developed with application systems and learning content that can meet the needs of students in online learning so that they can develop students' understanding and experience in learning using digital devices.

\subsection{Self-Regulated Learning}

Self-Regulated Learning is guided by the philosophy of progressivism which emphasizes increasing the ability of students through independence, experience, and always obtaining personal changes that can lead to the creation and appreciation of students in the learning process [16] In addition, learning independence is guided by the educational philosophy of Ki Hadjar Dewantara called the philosophy of education among which is a convergence of the philosophy of progressivism regarding the natural ability of students to overcome the problems faced by providing the widest possible freedom of thought [17].

In their research, Jossberger, Brand-Gruwell, van de Wiel, \& Boshuizen [18] argue that Self-Regulated Learning is a promising skill to achieve educational goals. The process of learning and learning without reflection and experience seems insufficient. It can be understood that learning independence is a skill possessed by students to support the learning and learning process in a relaxed and learning experience for each student.

According to Barry J. Zimmerman, Self-Regulated Learning takes from social cognitive theory to create the concept of Self-Regulated Learning using how students can be active in academic tasks and improve cognitive abilities [19]. In detail about the social cognitive theory that when students experience feedback from their environment or themselves, they monitor performance and make adjustments to improve outcomes [20].

Learning independence has six components based on the results of Dembo \& Seli's research [21], the six main components of learning independence are as follows.

a. Motivation (Motivation)

b. Methods of learning

c. Use of time

d. Physical environment (Physical Environment)

e. Social environment

f. Monitoring performance. (Monitoring Performance)

Motivation is self-control to motivate in achieving goals, develop confidence about the ability to perform tasks, and maintain confidence in the goals of many distractions when learning independently. Learning methods can be interpreted that how to use an effective SLR strategy. Furthermore, the time use component influences self-regulation. Physical and social environment, self-regulation of the social environment is related to the ability of students to determine when they need to work alone or with others, or when it is time to seek help from educators, tutors, peers, or other sources. Monitoring performance, it can be understood how students can control performance by criticizing their performance. These six components affect the SLR process so that it runs well, the main factor in SLR is how students can control their motivation in doing Self-Regulated Learning.

\subsection{Pancasila Education \& Civic Education Learning in $21^{\text {st }}$ Century Education}

The curriculum that applies in universities that support the 21st-century education pattern in the industrial era 4.0 is the Merdeka Belajar Kampus Merdeka (MBKM) Curriculum. Pancasila Education \& Civic Education courses guided by the MBKM Curriculum, Merdeka Belajar Kampus Merdeka (MBKM), learning is prepared to be able to answer the challenges of the 21 st Century known as the disruptive era or the digital era, Pancasila Education \& Civic Education Courses in the MBKM Curriculum, MBKM requires higher education to apply for these courses, this is based on Pasal 35, Undang-undang No. 12 Tahun 2012 tentang Pendidikan Tinggi (Higher Education), the Pancasila Education and Civic Education courses are required to be included in the learning process in higher education, of course, this becomes more of a 
concern when the Pancasila Education and Civic Education lecture processes are integrated into the 21 st-century education pattern in the industrial era 4.0.

Thus it can be understood that the Pancasila Education \& Civic Education curriculum is prepared to develop the competencies of students who can face the challenges of the 21 st century, of course, this is based on conceptual civic education such as civic knowledge, civic disposition, and civic skills, this concept is expected to be able to shape students who are digitally literate and able to adapt in the $21 \mathrm{st}$ century, this can be understood as digital citizenship. In the 21st century in learning Pancasila Education \& Civic Education, along with the ability of students who are digital technology literate, digital technology-based learning needs to be mastered by educators. Learning media that can be accessed through digital technology provide learning resources to meet student learning needs so that learning objectives are achieved effectively.

Civics is currently being developed to foster students' understanding and ability to understand digital technology-based information and use, changing, as well as creating new information based on digital technology needed in learning the fact that students are digitally literate, then in presenting learning, it must be based on the national education standard for students "National Educational Technology Standards For Students" (NETS-S) in the century 21 as Creativity and Innovation, Communication and collaboration, Research and fluency of information Critical thinking, problemsolving, and decision making, Digital citizenship, Technology operations, and concepts technology. [22]

In the era of digital technology, based on the explanation from NETS-S (National Educational Technology Standards for Students) above, it can be interpreted that teachers are no longer a source of knowledge, as in conventional learning models. On the other hand, teachers act as facilitators, dynamists, motivators, and evaluators by designing learning situations that focus on active student involvement to develop experiences, and the ability to use knowledge to generate new ideas. Teachers should be able to design lessons, taking into account NETS-S and available collaborative resources, and creatively and using technology and media.

\section{METHODS}

This study uses a quantitative approach, with the design used in this study being a survey research design. The type of cross-sectional survey is a research design that collects data at one time to the sample [23]. The researcher used a cross-sectional survey design to measure the behavior of the population through the sample regarding the level of learning independence as a research variable.
Participants are students of the compulsory subject of Pancasila Education \& Civic Education curriculum who have installed and used a mobile learning application on a course Pancasila Education \& Civic Education of 384 students. Data were collected from students who used ML applications in the Civic Education course on the blended learning (BL) system in 2021 as the primary sampling unit.

The total population of students who use mobile learning is 384 students using the Slovin formula at an error rate of $5 \%$. Determination of the number of samples is based on the table Krejcie \& Morgan, 1970 [24] and Slovin's formula can be understood that from 384 total population, researchers determine 196 samples. Thus, the results of this study can be generalized to all students who use applications mobile learning in the lecture content of Pancasila Education \& Civic Education at the Universitas Pendidikan Indonesia.

The technique of selecting students as samples is a systematic random selection procedure. The type of data analysis used to support this research is the univariate analysis and bivariate analysis. Univariate analysis is an analysis that describes the characteristics of each variable studied, to present this analysis using cross-tabulation analysis techniques, this technique aims to show and find out descriptive statistical data using cross-tabulation, this crosstab is used to determine and identify correlations between variables, while To test the correlation between variables, the researcher used bivariate analysis which aims to determine and test the positive and negative relationship or close or not between variables, the test used in this analysis using the Chi-Square test.

\section{RESULT AND DISCUSSION}

In this section regarding the interest and satisfaction of students when using ML in supporting student learning independence, there are several survey results which will then be further processed in bivariate data processing and examined in the discussion section, the provisional results of univariate data processing show that most of the results The survey conducted regarding student perceptions of student engagement and satisfaction when using ML was 125 students $(63.5 \%)$ stating it was important that through mobile learning students become like researchers who collect data and information themselves, and as many as 97 students (48.5\%) stated It is very important through ML that students can read information easily and completely sequentially to understand the material well independently, then related to the fact that after students use applications ML, the most survey results are 137 students (68.5\%) stated that they had felt through ML that students had evolved from passive to active learners, and 66 students $(33.0 \%)$ stated that they had very much implemented ML which made it easy for students to use applications in the independent study process and even prepare for the final exam. 
From this data, most students have a perception about ML that students can collect their data and information during online learning, therefore, in supporting online learning using tools ML, the characteristics of collecting data and information themselves in the content and substance of lectures need to be considered. This is done, it aims to increase student interest and satisfaction in using ML which in turn can motivate students to study independently. The Survey conducted shows that by using ML during online learning, students can evolve from passive learners to active learners, $\mathrm{ML}$ is able have a significant effect on the interest and ability of students to become active learners in online learning by using applications ML in the Pancasila Education \& Civic Education at the Universitas Pendidikan Indonesia.

Thus, in this section regarding the interest and satisfaction of students in using ML to support independent learning, most survey results show that students expect that applications ML can support them in learning by being able to collect data and information independently, besides that students expect through ML they easily and completely read information and materials in sequence. Then after students use the application they feel they have evolved from passive to active learners, then students also feel it is easy to get material sequentially by using applications mobile learning to prepare for the final exam.

Based on the results of a survey conducted by researchers regarding the use of applications ML in online learning, it shows that most students feel it is important $(52.5 \%)$ and very important (45.5\%) if applications ML become a place to improve students' abilities to become an active learner. Then, after students use applications mobile learning, students feel this has been accomplished by $(68.5 \%)$ during lectures using ML which aims to evolve into active learners. According to a survey conducted, it shows that by using mobile learning during online learning, students can evolve from passive learners to active learners.

This is closely related to the four pillars of education in 21 st-century education and the shift in the 21 st-century learning paradigm, [9] has created four pillars of education, namely 1) Learning to know, 2) Learning to do, 3) Learning to be, and 4) Learning to live together, from the statement it can be understood that through the ML application, students can learn to know various materials, mastery of the material and have a willingness to learn for life is one of the most important things in 21 st-century education. Then, Litbang Kemendikbud [25] stated that there are four characteristics of learning in the 21 st century, one of which is information that is available anywhere and anytime, educators change learning that used to be centered on educators, as the only source of knowledge, into learner-centered learning. Learning is directed at encouraging students to find out from various sources of observation, not being told.
Therefore, from the statement, it can be understood that students can find out from various information for sources of knowledge, through ML students become active in seeking scientific information, and become one of the forums to improve students' abilities to become active learners, not just lecturers who only provide scientific information to students.

Furthermore, regarding the characteristics of student learning resources, according to the results of the survey findings in the field, most students have a perception of ML that students can collect their data and information during online learning, as many as $63.5 \%$ of students perceive that in using ML students can find information and collect data. Themselves to support them in independent learning after students use the application, they have felt the things they want to be contained in the learning application in ML.

Regarding the characteristics of students in finding sources of information in learning, this is related to the statement of the 21 st-century competency framework proposed by P21CS [10] that the 21st-century competency framework is one of which is information media and technology, mastery of information media, and technology is the basis for students as citizens. Digital technology in supporting 21 st-century competencies, further explained by Litbang Kemendikbud [25] the characteristics of 21 st-century education patterns are Information (available anywhere, anytime, and anywhere). This 21 st-century education pattern directs students to find out from various sources of information and observations, not just being told by educators in the learning process in the classroom.

Arif and Aulia [26] describe nine elements of digital citizenship, one of which is that digital access can be interpreted about society and the patterns that exist in society in accessing information technology that can support the implementation of Civics learning. Therefore, students as digital citizens and in the Civics learning process elements of digital citizens as citizens who can access information are things that must be considered, of course with the use of this application mobile learning students can obtain information on digital media in supporting Civics learning. Furthermore, Smaldino, et al [22] describes the national educational technology standards for students, one of the standards expressed is, research and fluency of information, students can apply digital tools to collect, evaluate, and use the information to support learning in the classroom.

Thus it can be understood that the characteristics of information sources in supporting the learning process of Pancasila Education \& Civic Education using ML It is very necessary for supporting students to study independently and prepare themselves to live in an era of openness, this is evidenced by the development of Science and Technology. In the era of digital technology based on the NETS-S (National Educational Technology Standards For Students) explanation that 
lecturers are no longer a source of knowledge, but students can seek their information and knowledge to support them in independent study, lecturers need to design student-focused learning (student center), in addition to preparing for life in the 21 st-century education pattern, of course, this provides benefits in student learning independence.

After the researchers provide the results of an objective of the findings using univariate analysis techniques, the researchers will then analyze and explain the results of data processing using bivariate analysis techniques by conducting in-depth studies and analysis related to the results of research using bivariate analysis aimed at to find out and test the positive and negative relationship or close or not between variables. The following is the correlation between student component statements and their implementation in the practice of learning Pancasila Education and Civic Education at UPI using ML.

Table 1 Correlation of student components with the implementation of learning practices

\begin{tabular}{|c|c|c|c|c|c|c|}
\hline & & Student & \begin{tabular}{|c} 
Component \\
Lecturer
\end{tabular} & $\begin{array}{c}\text { Component } \\
\text { Teaching } \\
\text { Material } \\
\end{array}$ & $\begin{array}{c}\text { Component } \\
\text { Technology \& } \\
\text { Learning } \\
\text { Menu } \\
\end{array}$ & $\begin{array}{l}\text { Practical Using } \\
\text { mobile learning }\end{array}$ \\
\hline $\begin{array}{l}\text { Student } \\
\text { Component }\end{array}$ & $\begin{array}{l}\text { Pearson } \\
\text { Correlation } \\
\text { Sig. } \\
\text { (2-tailed) } \\
\mathrm{N}\end{array}$ & $\begin{array}{r}200200 \\
200\end{array}$ & $\begin{array}{c}.743^{* *} \\
.000\end{array}$ & $\begin{array}{c}.745^{* *} \\
.000\end{array}$ & $\begin{array}{c}.713^{2 *} \\
.000 \\
200\end{array}$ & $\begin{array}{r}.929^{* *} \\
\quad .000 \\
\text { on } 200\end{array}$ \\
\hline
\end{tabular}

Value of Pearson Correlation to student component of $\mathbf{0 . 9 2 9}$, means that the relationship between practical teaching and Pancasila Education \& Civic Education using learning applications ML on a system blended learning with a student component is very strong. So, the more frequent and the implementation of activities using learning applications ML by students will lead to an increase in the practice of learning Pancasila Education \& Civic Education at UPI by using learning applications ML on the system blended learning.

Table 2 Effect of student identity with student components

\begin{tabular}{|l|r|r|r|r|}
\hline Model & R & R Square & Adjusted R Square & Std. Error of the Estimate \\
\hline 1 & $.929^{3}$ & .863 & .863 & 4465 \\
\hline
\end{tabular}

Rated R-Square at this result showed a value of .0863 or $86.3 \%$. This value means that variations in all student identity variables can affect changes in student component variables by $86.3 \%$, the remaining $13.7 \%$ is influenced by other variables outside the model. The terms of the relationship between variables are good or not, if the R-Square value is above $50 \%$, it means it is good, if it is below $50 \%$, it means it is not good. Thus, the relationship between Pancasila Education \& Civic Education practices with the student component is very closely related.

From the results of a survey conducted using univariate analysis techniques, namely regarding student perceptions of student relevance and satisfaction when using mobile learning, 125 students $(63.5 \%)$ stated that it is important that through ML students become like researchers who collect data and information themselves, and as many as 97 students $(48.5 \%)$ stated that it was very important through ML that students could read the information easily and completely in sequence to understand the material well independently, then related to the fact that after students used ML applications, the most survey results were 137 students $(68.5 \%)$ stated that they had felt through mobile learning that students had evolved from passive to active learners, and 66 students $(33.0 \%)$ stated that they had very much implemented mobile learning which made it easy for students to use applications in the independent learning process and even prepare for the final exam.

Then, from the results of data processing with the correlation/attachment technique, it can be understood that the value of the Pearson Correlation for the student component is 0.929 , meaning that there is a very close relationship in the Pancasila Education \& Civic Education by using ML to support student learning independence. According to the survey results, the main factor is the student's factor Barry J. Zimmerman \& Risemberg and Rizana et al., [27], [28] explained that the main component in supporting student learning independence is student motivation. Learning Independence is guided by $\mathrm{Ki}$ Hadjar Dewantara's educational philosophy called the philosophy of education among which is a convergence of the philosophy of progressivism regarding the natural ability of students to overcome the problems faced by providing the widest possible freedom of thought. [17]

Ackoff and Dreemberg re-emphasized that "education does not depend on teaching, but rather on the self-motivated, curiosity and self-initiated actions of the learner" [11]. Education does not depend on the learning process but the motivation of students. In every student there is motivation in learning, student learning motivation that can affect student success in independent learning by using ML is the presence of content and substance in ML that suits the needs and desires of students, this can generate student interest and satisfaction. the use of mobile learning applications, so that they can influence and motivate students to study independently by using mobile learning applications in Pancasila Education \& Civic Education. Budimansyah and Pangalila argue Psychopedagogically, what is learned is believed to make a meaningful contribution for students to answer the challenges of life in the 21 st century, to strengthen essential insights, and to provide aspirations for further education. [29]

Students as digital citizens Ribble \& Bailey identify nine elements that together form digital citizenship, namely "digital access, digital commerce, digital communication, digital literacy, digital ethics, digital law, rights and obligations of citizens. digital state, digital health and wellness, and digital security" [30]. 
Students as digital citizens to face the challenges of $21^{\text {st }}$-century education need to be skilled in the use of digital access, digital literacy, digital communication, and digital ethics both with E-learning, B-Learning, or even M-learning processes. Skilled in mastering digital media, students easily access various learning content using applications ML, of course, the balance between the motivations of students and being skilled in the use of digital media becomes the main role in increasing student motivation in accessing learning media, features, and various learning strategies by using ML.

"Among these studies, common motivating factors or benefits of mobile learning expressed by students were quick and easy access to information, course content, and learning resources; the ability to upload content; participating in discussion boards; and the immediacy of contact between students and with faculty" [31]-[33] factors that can motivate students to use applications ML are speed of information, learning content, learning resources, ease of uploading assignments, and discussion forums. Budimansyah, Suryadi and Rasjidi found that teaching licensure insignificantly affected student achievement; the teaching license has become a symbol of credentials rather than the real competencies of teachers. Students' academic achievement, too, was determined by their socio-economic background more strongly than that by the competencies of certified teachers. [34]

Thus, students as digital citizens need to be skilled in the use of digital media, students are skilled in the use of digital media, students easily use and access material on applications ML, then according to the results of data processing and previous research, the main factor in learning independence is the motivation, through varied and innovative learning content, speed of information, ease of access any literature can motivate students to study independently in Pancasila Education \& Civic Education lectures by using applications ML.

\section{CONCLUSION}

From the results of the study, in general, students using the ML application in Pancasila Education \& Civic Education are satisfied because students are more quota efficient and lighter on bandwidth it becomes easier to understand, speed of information, ease of access for any literature can motivate students to learn independently by using ML, students as digital citizens need to be skilled in the use of digital media, after students are skilled, students will easily use and access applications of ML. Through varied, innovative learning content, speed of information, ease of access for any literature can motivate students to learn independently by using ML.

Students experienced satisfaction in learning Pancasila Education \& Civic Education using mobile learning. The use of mobile learning can be a solution to the effectiveness of digital learning in the $21 \mathrm{st}$ century. Mobile learning provides convenience in student learning in the digital era. The ease of access to materials or content in learning, the use of cheaper quotas, and the flexibility of learning without space and time limits in mobile learning provide satisfaction for students, thus encouraging students to study independently. Student independence in learning using mobile learning supports success in learning in the digital era. Therefore, mobile learning can be developed into an interesting and effective learning tool that can provide learning satisfaction to students so that students' independence in learning can be built.

\section{REFERENCES}

[1] Miniwatts Marketing Group, "Top 20 countries with the highest number of internet users," Intenet World Stat, 2018.

[2] A. Butler, M. A. Camilleri, A. Creed, and A. Zutshi, "The Use of Mobile Learning Technologies for Corporate Training and Development: A Contextual Framework," in Strategic Corporate Communication in the Digital Age, Emerald Publishing Limited, 2021, pp. 115-130.

[3] M. Sarker, M. Wu, Q. Cao, G. . Alam, and D. Li, "Leveraging Digital Technology for Better Learning and Education: A Systematic Literature Review," Int. J. Inf. Educ. Technol., vol. 9, no. 7, pp. 453-461, 2019, doi: 10.18178/ijiet.2019.9.7.1246.

[4] D. E. Nugraheny, "Survei KPAI: 43 Persen Siswa Keluhkan Kuota Internet untuk Pembelajaran Daring," Kompas.com, 2020. [Online]. Available: https://nasional.kompas.com/read/2020/08/08/102 65321/survei-kpai-43-persen-siswa-keluhkankuota-internet-untuk-pembelajaran. [Accessed: 22-Feb-2021].

[5] A. Collins and R. Halverson, "The second educational revolution: rethinking education in the age of technologyj cal_339 18..27," Blackwell Publ. Ltd J. Comput. Assist. Learn., vol. 26, no. 1, pp. 18-27, 2010, doi: 10.1111/j.13652729.2009.00339.x.

[6] C. Quinn, "Get ready for m-learning," Train. Dev., vol. 20, no. 2, pp. 20-21, 2001.

[7] S. Pereira, J. Fillol, and P. Moura, "Young people learning from digital media outside of school: The informal meets the formal," Comunicar, vol. 27, no. 1, 2019, doi: 10.3916/C58-2019-04.

[8] Y. Wang et al., "Revisiting the Blended Learning Literature: Using a Complex Adaptive Systems Framework Published by : International Forum of Educational Technology \& Society Linked references are available on JSTOR," Educ. Technol. Soc., 2015. 
[9] UNESCO, "Digital Literacy in Education," Moscow, 2011.

[10] P21CS, "21st Century Skills, Education \& Competitiveness," a Resour. Policy Guid., 2008, doi: 6th August 2016.

[11] R. L. Ackoff and D. Greenberg, "Turning Learning Right Side Up: Putting Education Back on Track," Chang. This, 2008.

[12] J. Traxler, "Defining mobile learning," Learning, 2005.

[13] E. Sadler-Smith, "Learning styles' and instructional design," Innov. Educ. Teach. Int., vol. 33, no. 4, pp. 185-193, 1996, doi: $10.1080 / 1355800960330405$.

[14] C. M. Reigeluth, "What is Instructional Design Theory and How Is it Changing? (93) The Learner-Centered Paradigm of Education View project Teacher Empowerment, Student Choice, and Equity in School Districts: A NonBureaucratic Alternative for School Organization and Accountability View project," 1999.

[15] A. S. Sadiman, Media pendidikan: Pengertian, pengembangan, dan pemanfaatannya. Jakarta: PT. Raja Grafindo Persada, 2009.

[16] V. R. Triyanto. Salu, "Filsafat Pendidikan Progresivisme dan Implikasinya dalam Pendidikan Seni di Indonesia," Imajin. J. Seni, 2017.

[17] Henricus Suparlan, "Filsafat pendidikan Ki Hadjar Dewantara dan sumbangannya bagi pendidikan Indonesia," J. Filsafat, 2015.

[18] H. Jossberger, S. Brand-Gruwel, M. W. J. van de Wiel, and H. P. A. Boshuizen, "Exploring Students' Self-Regulated Learning in Vocational Education and Training," Vocat. Learn., vol. 13, no. 1, pp. 131-158, Apr. 2020, doi: 10.1007/s12186-019-09232-1.

[19] B. J. Zimmerman, S. Bonner, and R. Kovach, Developing self-regulated learners: Beyond achievement to selfefficacy. Washington, DC: American Psychological Association, 1996.

[20] M. K. DiBenedetto, "Self-regulation in Secondary Classrooms: Theoretical and Research Applications to Learning and Performance," in Connecting Self-regulated Learning and Performance with Instruction Across High School Content Areas, Cham: Springer International Publishing, 2018, pp. 323.

[21] M. H. Dembo and H. Seli, Motivation and Learning Strategies for College Success. 2016.
[22] S. E. Smaldino, D. L. Lowther, J. D. Russell, and C. Mims, Instructional technology and media for learning. New Jersey: Pearson Merrill Prentice Hall Upper Saddle River, 2008.

[23] J. W. Creswell, "Research Design: Pendekatan Kuantitatif, Kualitatif,dan Mixed (Edisi Ketiga),' in Pustaka Pelajar, 2012.

[24] R. V. Krejcie and D. W. Morgan, "Determining Sample Size for Research Activities," Educ. Psychol. Meas., 1970, doi: 10.1177/001316447003000308.

[25] L. Kemendikbud, "Pergeseran Paradigma Belajar Abad-21," 2013. .

[26] D. B. Arif and S. S. Aulia, "Kewargaan digital, penguatan wawasan global warga negara, dan peran PPKn," in Internasional Seminar "Pendidikan Kewarganegaraan sebagai Bidang Keilmuan dan Program Pendidikan dalam Konteks Penguatan Daya Saing Lulusan, 2016, pp. 393-398.

[27] B. J. Zimmerman and R. Risemberg, "Becoming a self-regulated writer: A social cognitive perspective," Contemp. Educ. Psychol., 1997, doi: 10.1006/ceps.1997.0919.

[28] A. F. Rizana, U. Y. K. S. Hediyanto, F. Ramadhan, and A. Kurniawati, "E-learning success determinants in higher education: A systematic literature review from users' perspective," in IOP Conference Series: Materials Science and Engineering, 2020, doi: 10.1088/1757-899X/830/3/032012.

[29] D. Budimansyah and T. Pangalila, "Social studies as citizenship transmission in Indonesian schools," in Social Studies Education in South and South East Asian Contexts, 2021.

[30] M. Ribble and G. D. Bailey, Digital citizenship. Washingthon: International Society for Technology in Education, 2007.

[31] J. Gikas and M. M. Grant, "Mobile computing devices in higher education: Student perspectives on learning with cellphones, smartphones \& social media," Internet High. Educ., 2013, doi: 10.1016/j.iheduc.2013.06.002.

[32] A. J. Martin, H. G. Nejad, S. Colmar, and G. A. D. Liem, “Adaptability: How students' responses to uncertainty and novelty predict their academic and non-academic outcomes," J. Educ. Psychol., 2013, doi: 10.1037/a0032794.

[33] E. Vasquez-Cano, "Mobile Distance Learning with Smartphones and Apps in Higher Education, Educational Sciences: Theory and Practice, 2014,” Educ. Sci. Theory Pract., 2014.

[34] A. Suryadi, U. Rasjidi, and D. Budimansyah, "Does teaching licensure boost student learning? Indonesia's answer," New Educational Review. 2017, doi: 10.15804/tner.2017.49.3.21. 